\title{
Yemen: Fejlfortolket eller fejlslagen
}

\section{Maria-Louise Clausen}

Den 25. januar 2014 beskrev FN's daværende særlige udsending i Yemen, Jamal Benomar, transitionen i Yemen som en kilde til inspiration for andre arabiske lande. Godt et år senere er transitionen gået i stå, og landet står på kanten af borgerkrig.

Yemen er længe blevet beskrevet som et land på kanten; på kanten af økonomisk sammenbrud, på kanten af politisk kaos. Men indtil januar 2015 har politisk pragmatisme, komplicerede alliancer og en lang tradition for dialog gjort det muligt at opretholde facaden af en fungerende stat. Da den stærkt internationalt støttede præsident Hadi og hans regering valgte at træde tilbage den 22. januar 2015, blotlagde det ikke kun statens svaghed, men også at den tre år lange transition ikke havde formået at reformere det politiske system i Yemen.

Men hvordan kan den nuværende krise i Yemen bedst forklares? Hovedargumentet i denne artikel er, at et ensidigt fokus på simple dikotomier; sunni vs. shia, Iran vs. Saudi-Arabien eller USA vs. al-Qaeda slører for en reel forståelse af den politiske kompleksitet i Yemen og de reelle politiske og ikke mindst økonomiske udfordringer, som landet står overfor.
Men først lad os kikke lidt tilbage for at forstå, hvad der muliggjorde fremhævelsen af Yemen som et af det arabiske forårs successer så sent som sidste år.

\section{Det yemenitiske forår}

Da de første yemenitiske demonstranter, inspireret af Ben Alis fald i Tunesien, gik på gaden $\mathrm{i}$ januar 2011, havde daværende præsident Salih tilsyneladende et fast greb om magten, selvom politisk ustabilitet snarere er reglen end undtagelsen $\mathrm{i}$ Yemen. Protesterne startede blandt unge universitetsstuderende, der ønskede en demokratisk og moderne stat.

Indledningsvis indtog den officielle opposition i Yemen, Joint Meeting Parties (JMP), der er en koalition af seks partier, herunder det sunni-muslimske Islah parti, en afventede position.

Dette ændrede sig i løbet af februar 2011, hvor de sluttede sig til protesterne og begyndte at kræve præsident Salihs afgang. Protesterne blev desuden støttet af huthierne, en oprørsbevægelse fra det nordlige Yemen, og en spirende uafhængighedsbevægelse i det tidligere Sydyemen kaldet Hiraak. Gradvist spredte protesterne sig til hele Yemen, og i løbet af foråret 2011 blev det klart, at præsident Salihs greb om magten var alvorligt svækket.

Maria-Louise Clausen er Ph.-d.-studerende ved Institut for Statskundskab, Aarhus Universitet. 
Præsident Salih havde i en årrække prioriteret sin nære familie og især sin søn over andre politiske allierede. Dette havde skabt fundamentet for splid i Yemens øverste elite, særligt mellem præsident Salih og al-Ahmar familien, ledere af Yemens vigtigste stammeforbund Hashid og partiet Islah samt General Ali Mohsin, en magtfuld militærleder, der havde støttet Salih, siden han blev præsident i Nordyemen i 1978.

I marts 2011 blev mere end 50 ubevæbnede demonstranter dræbt, hvilket blev startskuddet til at centrale aktører sluttede sig til protesterne mod Salih. Særligt afgørende var det, at General Ali Mohsin ikke bare trak sin støtte, men også udkommanderede soldater fra 1. panserdivision, som han kontrollerede, til at beskytte demonstranterne i Sana’a.

På det tidspunkt var der frygt for, at situationen ville eskalere til borgerkrig. Det internationale samfund med Golflandene i spidsen formulerede derfor en transitionsaftale, der skulle sikre en fredelig overgang fra præsident Salih til et nyt regime.

Efter kraftigt pres indvilligede præsident Salih $i$ at træde tilbage og overlade præsidentembedet til sin vicepræsident, Abd Rabbu Mansur Hadi. Til gengæld fik Salih og hans nærmeste familie immunitet for forbrydelser begået før og under protesterne i 2011, og Salih fik lov til at forsætte som formand for Yemens største parti, General People's Congress (GPC), der fastholdt 50 pct. af pladserne i et overgangsparlament, der også blev etableret som en del af transitionsaftalen. De øvrige pladser i parlamentet blev givet til oppositionspartiet, JMP.

Transitionsaftalen havde til formål at stabilisere det politiske system i Yemen, men selvom det lykkedes at forhindre borger- krig i 2011, skabte transitionsaftalen samtidig grobunden for den nuværende krise ved at fortsætte ekskluderingen af ikke bare de unge demonstranter, men også huthierne og den sydlige uafhængighedsbevægelse Hiraak fra centrale politiske beslutninger.

\section{Eliten beholder magten}

Transitionsaftalen kan bedst beskrives som en reorganisering af politisk magt $\mathrm{i}$ Yemen, fordi magten reelt blev fastholdt hos den samme snævre elite, der havde styret Yemen siden 1990. Det var et valg, der blev truffet for at hive Yemen væk fra kanten af kaos, men samtidig var det et pragmatisk valg om at foretrække den kendte djævel.

Inddragelse og dialog var dog en vigtig del af transitionsaftalen; unge, kvinder, civilsamfundet og alle de politiske grupperinger, der i årtier havde haft begrænset indflydelse, fik mulighed for at påvirke det fremtidige politiske system i en omfattende National Dialog Konference (NDC). Dialogkonferencen var tilsyneladende en succes, men imens de udvalgte repræsentanter diskuterede fremtidens Yemen på luksushotellet Möwenpick i Sana’a, blev dagligdagen stadig sværere og sværere for almindelig yemenitter.

Gradvist mistede mange interessen i dialogen, og det internationale samfunds fremhævelse af Yemen som en succeshistorie vakte mindre og mindre genklang hos den brede befolkning.

\section{Sunni vs. shia - en sekterisk konflikt?}

Et dominerende perspektiv beskriver konflikten i Yemen som en konflikt mellem sunni- og shia-muslimer. Huthierne tilhører en særlig gren af shia-islam, kaldet zaydi, mens majoriteten i Yemen - ca. 65 pct. - er sunni-muslimer. Men på mange måder er zaydi-grenen af shia-islam 
tættere på sunni-islam, som den praktiseres i Yemen end på shia-islam, som den praktiseres i Iran.

Historisk har der ikke været tradition for sekterisk konflikt i Yemen. Sekteriske forskelle spiller en rolle i den nuværende konflikt, men pointen her er, at det ikke bare er forkert, men direkte hæmmende for en forståelse af den nuværende konflikt, hvis den primært forstås som en konflikt mellem sunni- og shia-muslimer.

Det skyldes at huthierne er et produkt af den yemenitiske politiske historie. Det er en oprørsbevægelse med en overvægt af zaydier, men bevægelsen har også sunni-muslimske medlemmer, inklusive religiøse ledere. Samtidig er det langt fra alle zaydier, der er en del af huthi-bevægelsen. Man kan derfor ikke forstå huthierne som en shia-muslimsk sekt, der kæmper for at sprede deres forståelse af islam. Men hvad driver så huthierne?

Der er særligt tre faktorer, der har formet den nuværende huthi-bevægelse: For det første politisk og økonomisk marginalisering. Zaydierne regerede Nordyemen indtil 1970, hvor det såkaldte imamat efter en otte år lang borgerkrig blev væltet og erstattet med den nuværende yemenitiske republik. Siden 1970 har zaydierne levet på kanten af den yemenitiske stat, både bogstaveligt talt, da de er centreret i området Sa'ada, der ligger op mod grænsen til Saudi-Arabien, men også ved at Saada i meget begrænset omfang fik tilført ressourcer fra den yemenitiske stat, hvilket har ført til udbredt fattigdom og manglende udvikling i området.

For det andet har præsident Salih støttet udbredelsen af salafisme og wahhabisme i Sa'ada. Wahhabismen er kommet til Yemen fra Saudi-Arabien, blandt andet via migrantarbejdere, der konverterede $\mathrm{i}$ Saudi-Arabien og derefter vendte tilbage til Yemen. I løbet af perioden blev der åbnet skoler og moskeer med støtte fra Saudi-Arabien, der spredte salafismen som et alternativ og en udfordring af zaydiernes høje status, der på trods af imamatets ophør i 1962 forsat blev respekteret i Saada. Dette førte til en styrkelse af zaydi-identiteten, særligt hos unge mænd.

Og endeligt skete der for det tredje en militarisering af konflikten fra 2004. I 2004 sendte præsident Salih militæret til Saada for at anholde Hussein al-Huthi, huthiernes daværende leder, på grund af hans kritik af regimet. Hussein al-Huthi blev dræbt, og konflikten eskalerede til en cyklus af kampe og våbenhviler indtil 2010. Regimets hårdhændede reaktion i Sa'ada skabte udbredt vrede og mistillid mod staten og hæren, også blandt ikkezaydier i Saada. General Ali Mohsin, der blev anset for at være den mest magtfulde mand efter præsident Salih, førte an i angrebene mod huthierne.

Dette forklarer, hvorfor huthierne specifikt angreb den såkaldte Firqa-lejr (divison), hjemsted for 1. panserdivision, der var ledet af General Ali Mohsin, da de overtog hovedstaden Sana'a i september. Ali Mohsin undslap og flygtede ud af Yemen.

Det var disse faktorer, der formede huthi-bevægelsen til en gruppe med begrænset tiltro til den politiske elite $\mathrm{i}$ Sana’a efter årtiers marginalisering og økonomisk udsultning. Da huthierne overtog Sana'a i september 2014 var det med stor folkelig opbakning, netop fordi de fokuserede på behovet for økonomiske og politiske reformer, herunder en indsats mod korruption, og selvfølgelig frem for alt etablering af sikkerhed. Temaer der vækker bred genklang i Yemen - uanset om man er zaydi eller sunni. 
Det er en ofte gentaget sandhed at saudierne foretrækker et stabilt, men svagt Yemen. Sagt med andre ord ønsker saudierne hverken en stærk udfordrer eller totalt kaos i deres baghave.

\section{Iran versus Saudi-Arabien}

Det næste dominerende perspektiv beskriver konflikten i Yemen som en stedfortræderkrig mellem Iran og SaudiArabien.

Der er ingen tvivl om, at især SaudiArabien er en central aktør i Yemen, og at Saudi-Arabien opfatter Iran som en potentiel regional trussel. Men saudiernes politik i Yemen skal primært forstås som et forsøg på at forhindre det yemenitiske kaos i at brede sig ind over de to landes fælles grænse.

Der er et regionalt aspekt i den nuværende konflikt i Yemen, som er blevet vigtigere og vigtigere, efterhånden som krisen har fået lov til at udvikle sig, men det er ikke det samme som, at krisen bedst forstås igennem en regional linse.

Det er en ofte gentaget sandhed at saudierne foretrækker et stabilt, men svagt Yemen. Sagt med andre ord ønsker saudierne hverken en stærk udfordrer eller totalt kaos i deres baghave. Yemen har primært bevæget sig på kanten af kaos, så saudierne har prioriteret at forhindre, at det kaos spreder sig ind over deres grænse. Det fysiske symbol på dette er den igangværende konstruktion af en næsten $1.800 \mathrm{~km}$ mur på grænsen mellem de to lande som et fysisk forsøg på at inddæmme Yemen.

Men det sker også ved, at saudierne køber sig til indflydelse, både ved direkte støtte til den yemenitiske stat og ved støtte til udvalgte sheiker og andre vigtige personer. I takt med at huthiernes indflydelse voksede, blev Saudi-Arabien i stigende grad bekymret ved udsigten til at have et Iran-venligt regime i Yemen.
I løbet af 2014 forholdt regimet i Riyadh sig afventede over for huthiernes fremmarch i Yemen. De fleste observatører af relationen mellem Yemen og Saudi-Arabien har peget på to mulige årsager til dette. For det første at det saudiske regime forberedte sig på en reorganisering i forbindelse med King Abdullahs sygdom og efterfølgende død, og for det andet at huthierne indledningsvist havde fokus på økonomiske og politiske reformer uden direkte at udfordre præsident Hadis position.

Men mens saudierne forholdt sig afventende, greb Iran muligheden og placerede huthierne ind i en fortælling, hvor den iranske model gradvist spredes over Mellemøsten, én hovedstad af gangen.

Relationen mellem huthierne og Iran har to dimensioner; hvad der er, og hvad der kan blive. Der går sejlivede rygter om våbenleverancer fra Iran til huthierne, men hvorvidt og i hvilket omfang er vanskeligt at dokumentere. Under alle omstændigheder er det usandsynligt, at huthierne har ageret som agenter for Iran.

Huthierne selv anerkender gerne en vis beundring for Iran og særligt Hizbollah, men har indtil videre benægtet, at de er afhængige af iransk assistance. Iran derimod tager gerne æren for huthiernes bedrifter, men iagttagere peger på, at disse udtalelser skal forstås i sammenhæng med et iransk ønske om at skabe en fornemmelse af forsat fremdrift og fremtid for den iranske revolution. Det betyder dog ikke, at den nuværende sympati og udveksling ikke kan udvikle sig.

Uafhængigt af den præcise relation mellem huthierne og Iran, så booster huthier- 
nes øgede indflydelse i Yemen i øjeblikket Irans regionale indflydelse. Samtidig kan den saudisk-ledede intervention og begrænsede bistand tvinge huthierne til at søge tættere bånd med Iran. Det er dog tvivlsomt, om iranerne vil være villige til eller i stand til at erstatte de store økonomiske bidrag, som Saudi-Arabien og de øvrige Golfstater har givet Yemen.

Men tilbage står, at relationen mellem huthierne og Iran har forudsætningerne for at blive en selvopfyldende profeti hvis de øvrige internationale aktører, herunder Saudi-Arabien og de øvrige Golfstater, samt USA og EU, vender ryggen til Yemen.

Konflikten i Yemen har udviklet sig til en arena for en regional magtkamp mellem Iran og Saudi-Arabien. Saudi-Arabien og Golf-landene er uden tvivl bekymrede over Irans stigende indflydelse i Mellemøsten, inklusive i Yemen. Det gælder særligt Saudi-Arabien, der opfatter det som en trussel mod deres regionale lederskab.

Det regionale element spiller altså en rolle i forhold til at forklare, hvorfor SaudiArabien intervenerede i Yemen, men det kan ikke forklare huthiernes hidtidige fremmarch. Huthierne er først og fremmest en national yemenitisk gruppe, noget de også selv fremhæver igen og igen. Deres kamp var en kamp mod marginalisering og for øget politisk indflydelse mere end en kamp for at skabe et nyt imamat og da slet ikke en kamp for at øge Irans indflydelse i Yemen.

Efter huthiernes magtovertagelse har de styrket deres bånd til Iran, men det ændrer ikke ved, at huthierne først og fremmest har en national dagsorden.

\section{Al-Qaeda på den Arabiske Halvø}

Det sidste perspektiv fokuserer på truslen fra al-Qaeda på den Arabiske Halvø, kaldet AQAP og den amerikanske indsats for at inddæmme, hvad amerikanerne har beskrevet som den største trussel mod USA. Yemen analyseres som en fejlslagen stat, der bedst forstås $\mathrm{og}$ håndteres som et udklækningssted for terrorister.

I det lys skulle man tro, at de yemenitiske ledere ligger søvnløse over truslen fra AQAP - hvis AQAP kan true verdens største militærmagt, så burde den yemenitiske stat være en formsag. Men AQAP har traditionelt ikke været blandt de mest magtfulde aktører i Yemen eller den største interne trussel mod det siddende regime.

Det amerikanske fokus på AQAP som hovedfjende er hverken blevet delt af Salih eller Hadi, da de har mødt langt alvorligere udfordringer mod deres autoritet. Selvom AQAP's aktivitet har været stærkt opadgående de seneste år, kan man argumentere for, at AQAP er et symptom på den manglende økonomiske og politiske udvikling fremfor en afgørende linse, der kan hjælpe os til at forstå det nuværende politiske kaos i Yemen.

Præsident Obama fremhævede i september 2014 antiterror-indsatsen i Yemen som et positivt eksempel for lande som Syrien og Irak. Præsident Hadi blev set som en loyal allieret i kampen mod terror, der til gengæld nød godt af amerikansk støtte. Men selvom præsident Hadi på den ene side var og er afhængig af international opbakning, så underminerede hans tætte samarbejde med amerikanerne samtidig hans legitimitet i Yemen.

Helt afgørende er droneangrebene og det generelle antiterror-samarbejde mellem Yemen og USA generelt upopulært i Yemen, også blandt det overvældende flertal, der ikke støtter AQAP.

Desværre for Hadi har en stor del af vreden over de amerikanske droneangreb været rettet mod ham og hans styre, fordi han tillod USA at gennemføre angreb på 
yemenitisk jord. Ydermere blev præsident Hadis samarbejde med amerikanerne og de øvrige vestlige lande set som udtryk for svaghed, hvor Hadi af sine politiske fjender kunne fremstilles som en marionetdukke, der besad præsidentposten på eksterne magters nåde.

Samtidig betyder amerikanernes manglende forståelse af den yemenitiske kontekst, at deres handlinger uforvarende kan styrke AQAP i interne magtkampe i Yemen. Et eksempel på det sidste er, at amerikanerne gennemførte flere droneangreb i Yemen efter præsident Hadis fratrædelse i januar 2014. Det var måske et amerikansk forsøg på at signalere til AQAP, at den nuværende krise ikke hæmmer USA's evne til at gennemføre angreb i Yemen, men angrebene støttede samtidig AQAP i deres propagandakrig mod huthierne. AQAP brugte droneangrebene til at anklage huthierne for at samarbejde med USA, fordi huthierne tilsyneladende accepterede, at droneangrebene forsatte.

AQAP har aktivt forsøgt at skabe en forståelse af, at konflikten mellem huthierne og AQAP er en konflikt mellem sunniog shia-muslimer. Som allerede beskrevet har der ikke været tradition for sekteriske konflikter i Yemen, men på grund af huthiernes hårdhændede behandling af politiske modstandere har der været en bevægelse, hvor flere ser AQAP som en modvægt til huthierne.

Dette ses også ved, at nogle stammer, der tidligere kæmpede mod AQAP, nu har allieret sig med AQAP i kampen mod en fælles fjende, huthierne. Samtidig har det nuværende sikkerhedsvakuum generelt øget AQAP's muligheder for at agere i Yemen. Den reelle trussel fra AQAP er dog svær at bedømme. Vurderinger af AQAP's størrelse svinger fra nogle få hundrede til flere tusinde, men det præcise antal og deres styrke er umuligt at bekræfte. Den tidligere præsident Salih overdrev jævnligt truslen fra AQAP som en metode til at øge amerikansk bistand, mens han reelt i perioder samarbejdede med AQAP for blandt andet at nedkæmpe huthierne. Der er dog ingen tvivl om, at utilfredsheden med det amerikanske antiterror program er større end opbakningen til AQAP. Det er derfor mange yemenitter, der mener, at AQAP ville blive mere svækkede af, at amerikanerne afslutter fremfor fortsætter deres droneprogram.

\section{Alternative perspektiver}

De tre tilgange til en forståelse af Yemen giver os hver især en brik i forstålsen af Yemen, men der er yderligere to faktorer, der bør inddrages, nemlig den svage yemenitiske stat og den økonomiske situation i Yemen. Den yemenitiske stat spiller ofte en sekundær rolle i forhold til personlige netværk og stammerelationer. Det har to konsekvenser:

For det første har et begrænset netværk af aktører infiltreret staten og alle de formelle beslutningsstrukturer. Kontrol med staten er vigtig, fordi den giver adgang til ressourcer, der finansierer dette netværk, men det er sjældent i de formelle statsinstitutioner, at afgørende beslutninger træffes.

For det andet har den yemenitiske stat $\mathrm{i}$ det meste af Yemens historie haft begrænset rækkevidde. Den yemenitiske stat kan ikke levere de mest basale ydelser, så stammer og andre ikke-statslige aktører varetager mange funktioner, som man ellers ville forvente var statens opgave for eksempel relateret til sikkerhed. Da yemenitterne demonstrerede mod præsident Salih i 2011, var håbet, at transitionen ville medføre politiske og økonomiske reformer. Da det ikke skete, mistede staten yderligere legitimitet, og det var med til at skabe en politisk åbning for huthierne.

Den anden faktor, Yemens økonomiske 
kaos, er helt afgørende. Uafhængigt af den politiske situation er økonomien faretruende tæt på et totalt kollaps. Yemen har længe levet for lånte penge, særligt tilskud fra Saudi-Arabien og Golfstaterne, og denne kilde er med huthierne magtovertagelse svundet ind.

Den økonomiske situation var med til at skabe opbakning til huthierne, der markedsførte sig som en ny start, der lovede at bekæmpe korruption og gennemføre økonomiske reformer. Men det viste sig hurtigt at være nemmere sagt end gjort for huthierne, særligt fordi de generelt virkede uforberedte på at gennemføre reelle reformer. Faktum er, at allerede inden den saudisk-ledede intervention levede mere end 50 pct. af befolkningen i Yemen under fattigdomsgrænsen. Interventionen har yderligere forværret den humanitære situation, samtidig med at det på nuværende tidspunkt er uklart i hvilket omfang Saudi-Arabien eller andre eksterne aktører har lagt en strategi for den fremtidige genopbygning af Yemen. Det er svært at se, hvordan der kan skabes politisk stabilitet i Yemen uden seriøs opbakning fra internationale donorer, herunder Golf-landene.

\section{Hvad så nu, Yemen?}

Denne artikel har argumenteret for, at simple dikotomier ikke kan forklare den nuværende krise i Yemen. Situationen i Yemen er kompleks og tæet forankret i den lokale yemenitiske politiske historie med et væld af aktører, der på skift samarbejder og modarbejder hinanden. Det er den nationale kontekst, der er afgørende for Yemens fremtid. Samtidig er det dog også klart, at Yemens fremtid ikke kan forstås uafhængigt af regionale aktørers interesser. Selvom konflikten oprindeligt var en håndterbar national magtkamp, har den nu udviklet sig til en regional styrkeprøve med sekteriske elementer. Huthierne havde indled- ningsvist en vis opbakning i den almindelige yemenitiske befolkning, fordi de markedsførte sig selv som et alternativ til de eksisterende eliter og den fastkørte politiske transition, samtidig med at de lovede økonomiske reformer.

Deres indledende popularitet gav dem en unik mulighed for at skabe reel politisk forandring ved at inddrage alle de grupper, der både før og efter præsident Salihs afgang blev ekskluderet fra det politiske system. Men allerede inden den saudisk-ledede intervention var de ude af stand til at leve op til deres løfter. I stedet for at genstarte implementeringen af resultaterne af den Nationale Dialog forsatte huthierne deres militære kampagne i samarbejde med tidligere præsident Salih.

Salih har forsat betydelig magt i Yemen, herunder kontrol med dele af den yemenitiske hær. Men alliancen mellem huthierne og Salih kan bedst beskrives som ustabil. Samtidig har har huthierne mødt stærk modstand i det sydlige Yemen.

Præsident Hadi har fået bred opbakning fra både nabolandene i Golfen og fra Vesten, men reelt er det svært at se, hvordan Hadi kan komme til at fungere som en reel præsident, især fordi han hverken har stor legitimitet, folkelig opbakning eller militær styrke. Det er vanskeligt at forestille sig, at han kan fungere som samlingspunkt for et forenet Yemen, herunder undgå at Sydyemen kræver uafhængighed. Siden 2007 har Sydyemen haft en voksende uafhængighedsbevægelse, som sandsynligvis vil være blevet styrket af huthiernes brutalitet i Aden.

Konklusionen er derfor, at der i øjeblikket ikke er nogen, der kontrollerer - eller har potentiale til at kontrollere - hele Yemen. I stedet kontrollerer forskellige grupper forskellige områder, og Yemen ligner et land i borgerkrig. 


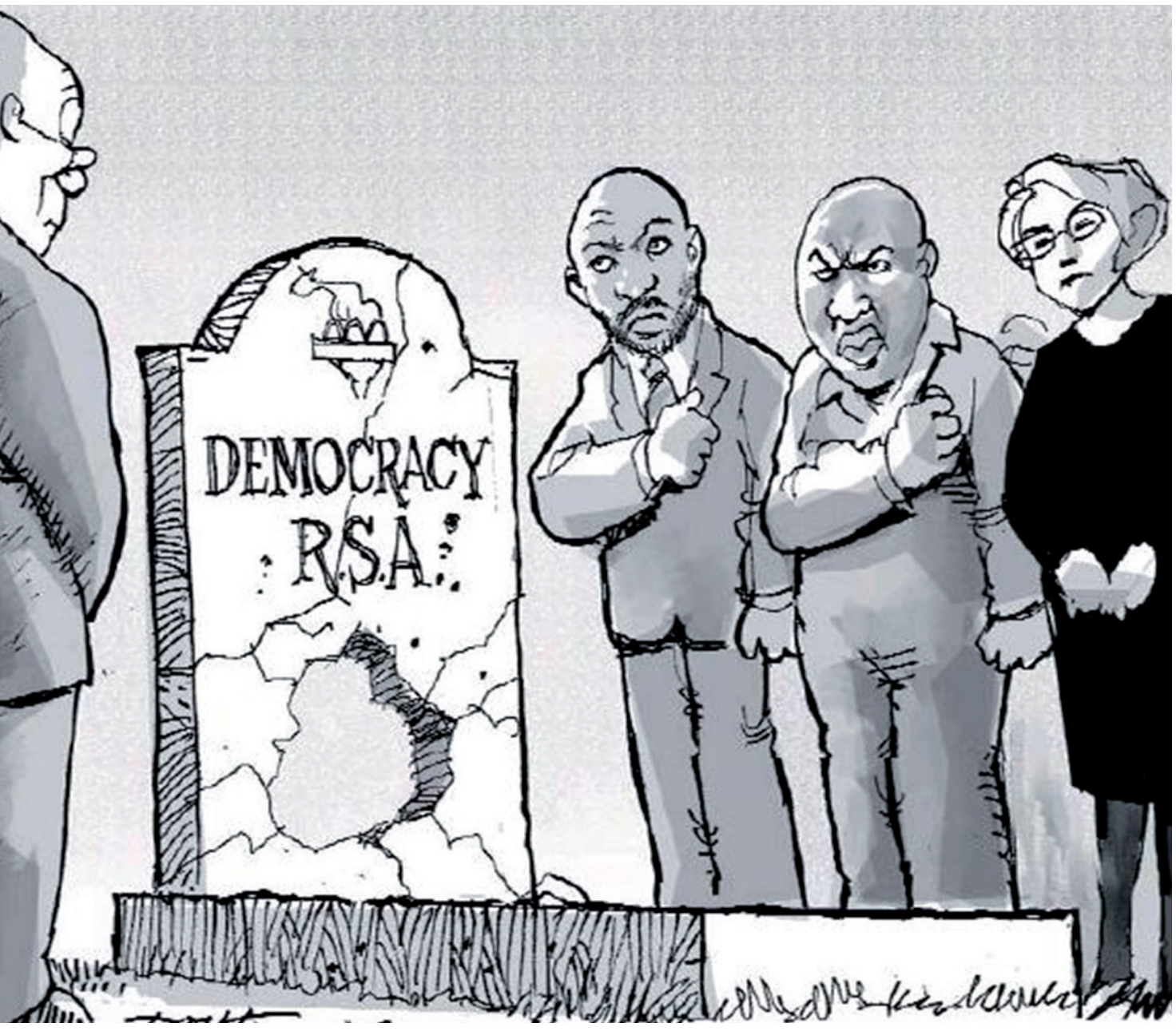

